\title{
CAMEL MILK AND THE AQUEOUS EXTRACT OF DANDELION LEAVES AS ADJUVANTS FOR CONTROLLING AGAINST LIVER INJURY
}

\author{
Marwa $^{1^{*}}$ M. Yousef, El-Hofi' M.A., Ashoush ${ }^{2}$ I.S., Soryal ${ }^{1}$ K.A. \\ and Safaa A. Ahmed ${ }^{3}$
}

1- Dairy Production and Technology Unit., Animal Breeding Dept., Desert Research Center, Cairo, Egypt.

2- Food Science Dept., Fac. of Agric., Ain Shams Univ., P.O. Box 68, Hadayek Shobra 11241, Cairo, Egypt.

3- Medicinal Food and Food Sci. Division, National Organization for Drug Control and Research (NODCAR), Giza, Egypt.

\section{*Corresponding author: marwa.net3@yahoo.com}

Received 8 September, 2019

Accepted 25 September, 2019

\section{ABSTRACT}

The liver disease all over the world had a more attention towards the prevention methods; balanced diet can be effective and protective. Therefore, the objective of this study was to investigate the hepatoprotective role camel milk; fermented camel milk; the aqueous extract of dandelion leaves (prebiotic); fermented camel milk fortified with the aqueous extract of dandelion leaves as (synbiotic product); camel whey and camel casein protein against carbon tetrachloride $\left(\mathrm{CCl}_{4}\right)$ induced liver injury in rats. Rats were divided into eight groups (eight rats each). Group one was served as normal control (NC), while the other seven groups were injected intraperitoneal in beginning of experimental with single dose from $\left(\mathrm{CCl}_{4}\right)$. Animals from group three to seven received orally camel milk; fermented camel milk; the aqueous extract of dandelion leaves; synbiotic product and whey camel milk; while, group eight received basal diets in which protein was replaced with $20 \%$ camel casein. All rats were feed for 45 days. The results indicated that all previous materials exhibited scavenging activity; liver injury control group (IC) revealed significantly increased in liver function (AST, ALT and ALP) and malondialdehyde (MDA) levels; whereas, decreased body weight gain, albumin and glutathione reduced (GSH) levels. Also, histological examination of hepatic showed more alteration due to $\left(\mathrm{CCl}_{4}\right)$ induced hepatocellular damage. While, treatment by the aqueous extract of dandelion leaves (prebiotic); camel milk; fermented camel milk; fermented camel milk forti- fied with the aqueous extract of dandelion leaves (synbiotic product); camel casein and camel whey protein resulted in a significant improvement in weight gain, liver function and oxidative stress parameters; also, suppresses the alteration in liver histology. It could be concluded that the aqueous extract of dandelion leaves (prebiotic); camel milk; fermented camel milk (probiotic product); fermented camel milk fortified with the aqueous extract of dandelion leaves (synbiotic product); camel casein and camel whey protein could be used as ingredients in functional foods for hepatoprotective.

Keywords: Camel milk, Probiotic, Dandelion, Liver Injury, Rats

\section{INTRODUCTION}

The liver is the most important organ involved in the metabolism and storage of nutrients (Mahan and Escott-Stump, 1996). The most common causes of liver disease (or liver failure) are toxic injury due to drug use, alcohol abuse, any type of liver infection, hypertension, sclerosing cholangitis and billiard cirrhosis (ADA, 2000).

World Health Organization (WHO) reported that $80 \%$ of the world population is primarily reliant on traditional methods of healing (Mueller and Mechler, 2005).

Many reports discussed the use of camel milk as a traditional method of healing. Badr et al (2012) demonstrated the benefits of why protein of camel milk for improving the healing and closure of diabetic wounds in a diabetic mice. Camel milk 
might be a promising new protein source for children allergic to cow milk protein (El-Agamy et al 2009). Camel s milk has medicinal properties, antibacterial and antiviral activity (El-ouardy et al 2011) which may be related to higher content of lactoferrin (Yagil et al 1994). Camel milk has been widely used as a traditional medicine for treating many diseases, including liver diseases (Magjeed, 2004). Milk protein-derived bioactive peptides are frequent components of food additives used for the formulation of functional foods (Huth et al 2004). Milk proteins play an important role in promotion of health and prevention of diseases (Meisel, 2005).

Probiotic bacteria in fermented dairy products are of interest for human health and diseases. Incorporation of probiotics as starter organisms has positive effect on probiotic cultures (Reid et al 2010; Heller, 2001). Probiotics stimulate the immune system, balancing of intestinal microbiota, potential reduction of inflammation, and the prevention of allergic hypertension, and cancer. (Parvez et al 2006).

Dandelion has been used as an herbal medicine due to its antidiabetic, choleretic, antirhematic, and diuretic properties (Schütz et al 2006). Recent studies have proved that it may reduce the risk of diseases, including inflammation and tumors (Kim et al 2007). For this reason, chicory is widely used as a functional food throughout the world for health promoting and technological properties. It was also found to have protective effect on acute liver inflammation induced by carbon tetrachloride in rats (Park et al 2010).

Therefore, the objective of the present research is to investigate the hepatoprotective role of camel milk ; fermented camel milk (probiotic product); the aqueous extract of dandelion leaves(Prebiotic product); fermented camel milk fortified with dandelion leaves aqueous extract (synbiotic product); camel whey proteins and camel casein against $\mathrm{CCl} 4$ induced liver injury in rats.

\section{MATERIALS AND METHODS}

\section{Materials}

Camel milk was collected from Camel in Marsa Matrouh research station, Egypt; dried dandelion (Taraxacum officinalis) leaves were obtained from local market, Egypt. Commercial kits used for determining alanine aminotransferase (ALT); aspartate aminotransferase (AST); alkaline phosphatases (ALP); albumin; malondialdehyde (MDA) and reduced glutathione (GSH) were purchased from
Biodiagnostic Co. Dokki, Egypt. Whereas the carbon tetrachloride $\left(\mathrm{CCl}_{4}\right)$ was obtained from ElGomhoreya Co., Cairo, Egypt. Meanwhile, 2,2diphenyl-2-picrylhydrazyl radical (DPPH) were purchased from Sigma-Aldrich Inc. (St Louis, MO, USA). In addition to, starter cultures of ABT-1 containing of (Lactobacillus acidophilus, Streptococcus thermophilus and Bifidobacterium bifidum) with potential probiotic properties were procured from (Chr. Hansen Laboratory Copenhagen, Denmark). Enzymes from used: Rennet FAR-M LIQUID (Chr. Hansen Middle East, Africa).

\section{Animals}

Male Albino Wistar rats with an average weight of $140 \pm 10 \mathrm{~g}$ were obtained from the Organization of Biological Products and Vaccines (Helwan Farm, Cairo, Egypt).

\section{Preparation of Aqueous Extract of Dandelion (Prebiotic)}

Aqueous extract of dandelion leaves (Taraxacum officinalis) was prepared according to the method described by Abdel-Salam et al (2009). Briefly, dandelion leaves powders was pulverized in a grinder ( $3 \%$ total dry matter), then was extracted with hot distilled water in an electric blender for $15 \mathrm{~min}$. The suspension was left at room temperature for one hour, and then filtered; first through cheese-cloth and then through filter paper (Whatman No.2). The clear aqueous extract was preserved in sterile dark bottles at $-20^{\circ} \mathrm{C}$ until further use.

\section{Preparation of probiotic and synbiotic camel milk}

Fermented camel milk was prepared by adding starter cultures of (Streptococcus thermophilus, Lactobacillus acidophilus and Bifidobacterium bifidum) according to the traditional method described by Tamime and Robinson (1999). While, synbiotic camel milk containing (probiotic and prebiotic) was prepared by combining equal volume of fermented camel milk (probiotic) with an equal volume (1:1) of dandelion aqueous extract (prebiotic).

Preparation of camel milk proteins (casein \& whey)

The method described by Mervat Gaffar, (2008) was followed by using raw camel skim milk 
pasteurized at $72^{\circ} \mathrm{C}$ for 15 sec., and then cooled to $35^{\circ} \mathrm{C}$. Rennet was added $(50 \mathrm{ml} / 150$ liters) to the milk and mixed for2-3minutes. After the complete coagulation of the milk, curd was cut into small pieces and the whey was separated by filtration through cheese muslin. The curd was washed several times with distilled water until no lactose was detected. Casein was stored at $-20^{\circ} \mathrm{C}$ until further use. The resultant casein contained $65 \%$ total protein on solids.

\section{Method of analysis}

\section{DPPH radical scavenging activity \%}

The methanolic extracts of camel milk; fermented camel milk (probiotic product); the aqueous extract of dandelion leaves (prebiotic); probiotic fortified with prebiotic (Synbiotic product); camel whey protein and camel casein were obtained as described by Bloor, (2001). The ability of methanolic extract samples to scavenge 2,2diphenyl-2-picrylhydrazyl radical (DPPH) free radicals were determined by the method described by Brand-Williams et al (1995). The percentage of scavenging effect was calculated from the decreased in absorbance at $517 \mathrm{~nm}$ against control according to the following equation:

$$
\begin{gathered}
\text { Scavenging activity } \%=\left[\left(A b s_{\text {control }}-A b-\right.\right. \\
\left.\left.S_{\text {sample }}\right) / A b s_{\text {control }}\right] \times 100
\end{gathered}
$$

\section{Biological experiment design}

The experiment was conducted on sixty four male Albino Wistar rats; they were housed in special cages under controlled conditions. The animals were fed on basal diet according to AIN-93 guidelines (Reeves et al 1993) and were provided with water ad-libitum during the experimental period.

The rats were randomly divided into eight groups with eight rats in each group. Group one was reserved as normal control (NC). Groups from two to eight, rats were administrated intraperitoneal (IP) injection with single dose of $2 \mathrm{ml} / \mathrm{kg}$ body weight by mixture of $(1: 1 \mathrm{v} / \mathrm{v} \mathrm{CCl} /$ paraffin) according to Małgorzata et al (2009). Group two kept as injury control (IC); each rat from group three to group seven received its weight corresponding dose (according to the fortnight weight) through oral gavage for camel milk; the aqueous extract of dandelion leaves; synbiotic product and whey camel milk in a dose of $1 \mathrm{ml} / 100 \mathrm{~g}$ body weight per day for successive six weeks. The calculation was based on a consumption of $275 \mathrm{ml} /$ day for a $70 \mathrm{~kg}$ human as reported by Rouanet et al (2010). While, group eight received basal diets in which protein was replaced with $20 \%$ camel casein for 45 days. The changes in body weight were recorded weekly, blood samples were also taken from the retro-orbital plexus of the eyes from all rats of each group at the end of the experiment; the liver was excised immediately after bleeding for histopathological examination. Serum was obtained from blood samples by centrifugation at $1500 \mathrm{rpm}$ for 15 $\mathrm{min}$ at an ambient temperature for analysis.

\section{Biochemical investigation}

\section{Liver marker enzymes}

The activities of serum alanine aminotransferase (ALT) and aspartate aminotransferase (AST) were determined colorimetrically at $505 \mathrm{~nm}$ according to Reitman and Frankel, (1957). While, the activity of alkaline phosphatase (ALP) was determined according to Tietz et al (1983) .Whereas, serum albumin was estimated according to the method of Doumas et al (1971).

\section{Oxidative stress parameter}

The Lipid peroxidation (LPO) in serum was determined by measurement of malondialdehyde (MDA) formation at $534 \mathrm{~nm}$ using the thiobarbituric acid reactive substances (TBARS) method as described by Ohkawa et al (1979). Whereas, reduced glutathione (GSH) in the serum was estimated by its reaction with dithio-bis-2nitrobenzoic acid (DTNB) according to Beutler et al (1963).

\section{Histopathological Examination}

Autopsy samples were taken from the liver of the different groups of rats and used for histological examination as described by Banchroft et al (1996).

\section{Statistical analysis}

Descriptive values of data were expressed as the Mean $\pm S E$ and they were analyzed statistically using the one-way analysis of variance ANOVA followed by Duncan's test. In all cases $p<0.05$ was used as the criterion of statistical significance by SAS program SAS, (2003). 


\section{RESULTS AND DISCUSSION}

\section{Scavenging activity of Dandelion, camel milk and their different prepared treatment}

The results of scavenging activity of the experimental materials are presented in Table (1). The scavenging activity (\%) in camel milk; fermented camel milk (probiotic product); dandelion aqueous extract (prebiotic); probiotic product fortified with prebiotic product (synbiotic product); camel whey and camel casein protein were 64.43, 75.97, $83.47,67.43,71.07,45.60 \%$ respectively. As can be noticed from the results that the highest scavenging activity were recorded in dandelion aqueous extract; these finding were coincided with those obtained by Yansong et al (2017) who reported that dandelion leaf crude extract possesses the highest DPPH scavenging activity than other plant parts. Followed respectively by probiotic camel milk $>$ camel whey protein $>$ synbiotic camel milk > camel milk > camel casein. These results are in harmonization with those obtained by Nishino et al (2000) who reported that increased radical scavenging activity was due to the protein peptides present in the fermentation.

Table 1. Scavenging activity \% of Dandelion, camel milk and their different prepared treatment

\begin{tabular}{|c|c|}
\hline Treatments & Scavenging activity $\%$ \\
\hline Camel milk & $64.43^{\mathrm{d}} \pm 0.26$ \\
Fermented camel & $75.97^{\mathrm{b}} \pm 2.44$ \\
milk(probiotic) & \\
Dandelion aqueous & $83.47^{\mathrm{a}} \pm 0.84$ \\
extract & \\
Synbiotic camel milk & $67.43^{\mathrm{cd}} \pm 2.64$ \\
Whey & $71.07^{\mathrm{bc}} \pm 1.49$ \\
Casein & $45.60^{\mathrm{e}} \pm 3.04$ \\
\hline
\end{tabular}

Data are mean $\pm S E, n=3$, Different uppercase letters in the same column represent statistically significant data at $5 \%$.

\section{Growth performance in rats}

The initial body weights of all rats groups were not significantly different, however, after 45 days of feeding; body weight gain were significantly lower in liver injury control group (IC) treated with $\mathrm{CCl} 4$ as compared to the normal control and other treatment groups (Table 2). On the other hand, rats received orally camel milk; fermented camel milk (probiotic product); dandelion extract (prebiotic product); ); probiotic product fortified with prebiotic product extract (synbiotic product) and camel whey protein increased significantly in weight gain and weight gain $\%$ in comparing with normal control and $\mathrm{CCl}_{4}$ treated groups. While, rats fed on diets contained camel casein recorded the highest body weight gain and weight gain \% in comparing with other treatment groups. With occurred higher increased in body weight gain compared to IC. These results hypothesized that the applied treatments may improve appetite and enhance weight gain.

\section{Liver function parameters}

The liver play important role as a major organ for detox our body from toxicant which we exposure daily from xenobiotics and drugs. The present study was focused on investigating the role of camel milk; fermented camel milk (probiotic product);); dandelion extract (prebiotic product); probiotic product fortified with prebiotic product (synbiotic product), camel whey and camel casein protein against $\mathrm{CCl}_{4}$ induced hepatic injury and to find the possible hepatoprotection.

Rats subjected to $\mathrm{CCl}_{4}$ developed significant hepatocellular injury as revealed from the higher serum activities of AST; ALT and ALP compared to normal control group and others treatment groups; also, the injury group noticed lower level from albumin which indicated to decreased the ability of the liver to create albumin due to liver dysfunction (Table 3). The increased serum of hepatic markers have been attributed to the liver injury, because these enzymes are placed in cytoplasmic area of the cell and are released into circulation in case of cellular damage Thnaian, (2012).

On the other hand, treatment by camel milk ; fermented camel milk (probiotic product); dandelion extract (prebiotic); probiotic product fortified with prebiotic product (synbiotic product), camel whey and camel casein protein exhibited a significant reduction in the levels of AST; ALT and ALP as compared with liver injury control rats group; also, improved the level of albumin to return to its normal level comparing to injury group. Camel milk could induce decrease in lipid peroxidation processes as well as increase in the activities of plasma protein and albumin in animal (Al-Fartosi, 2012).

\section{Oxidative stress parameters}

Table (4) shows the changes in the levels of malondialdehyde as an indication of lipid oxidation 
in serum of rats groups. Administration of camel milk; fermented camel milk (probiotic product);

Table 2. Growth performance parameters of rat's different experimental groups

\begin{tabular}{|c|c|c|c|c|}
\hline Parameters & $\begin{array}{c}\text { Initial weight } \\
\mathbf{( g )}\end{array}$ & $\begin{array}{c}\text { Final weight } \\
\mathbf{( g )}\end{array}$ & $\begin{array}{c}\text { weight gain } \\
\mathbf{( g )}\end{array}$ & $\begin{array}{c}\text { weight gain } \\
\%\end{array}$ \\
\hline $\mathbf{N C}^{\star}$ & $142.4^{\mathrm{a}} \pm 1.46$ & $150.2^{\mathrm{c}} \pm 1.02$ & $7.80^{\mathrm{c}} \pm 2.01$ & $5.53^{\mathrm{c}} \pm 1.46$ \\
$\mathbf{I C}^{\star *}$ & $140.0^{\mathrm{a}} \pm 2.44$ & $116.2^{\mathrm{d}} \pm 4.694$ & $-21^{\mathrm{d}} \pm 5.99$ & $-15.62^{\mathrm{d}} \pm 4.24$ \\
Camel milk $^{\text {Groups }}$ & $147.2^{\mathrm{a}} \pm 5.49$ & $170.8^{\mathrm{b}} \pm 4.586$ & $23.6^{\mathrm{b}} \pm 6.852$ & $16.67^{\mathrm{b}} \pm 5.29$ \\
FCM $^{\star \star *}$ & $149.2^{\mathrm{a}} \pm 2.09$ & $162.0^{\mathrm{bc}} \pm 3.162$ & $12.8^{\mathrm{bc}} \pm 3.136$ & $8.6^{\mathrm{bc}} \pm 2.11$ \\
Dandelion & $142.4^{\mathrm{a}} \pm 0.40$ & $159.2^{\mathrm{bc}} \pm 6.183$ & $22.8^{\mathrm{b}} \pm 5.678$ & $16.8^{\mathrm{b}} \pm 4.16$ \\
Synbiotic & $147.2^{\mathrm{a}} \pm 5.678$ & $158.6^{\mathrm{bc}} \pm 4.578$ & $11.4^{\mathrm{bc}} \pm 2.039$ & $7.9^{\mathrm{bc}} \pm 1.59$ \\
Whey & $151.2^{\mathrm{a}} \pm 5.314$ & $162.2^{\mathrm{bc}} \pm 6.931$ & $11.0^{\mathrm{bc}} \pm 2.489$ & $7.2^{\mathrm{bc}} \pm 1.61$ \\
Casein & $144.8^{\mathrm{a}} \pm 2.576$ & $207.2^{\mathrm{a}} \pm 3.929$ & $62.4^{\mathrm{a}} \pm 3.187$ & $43.2^{\mathrm{a}} \pm 2.43$ \\
\hline
\end{tabular}

Data are mean $\pm S E, n=5$, Different uppercase letters in the same column represent statistically significant data at 5\%; "Normal control group; "Injury control group; "**Fermented camel milk.

Table 3. Liver functions of different experimental groups

\begin{tabular}{|c|c|c|c|c|}
\hline Groups & AST (U/I) & ALT (U/I) & Albumin (mg/dl) & ALP (U/I) \\
\hline$N^{*}$ & $135.60^{\mathrm{e}} \pm 3.37$ & $50.60^{f} \pm 4.70$ & $3.86^{a} \pm 0.21$ & $135.00^{e} \pm 8.80$ \\
\hline$I^{* *}$ & $214.40^{a} \pm 9.70$ & $160.40^{a} \pm 4.55$ & $2.42^{c} \pm 0124$ & $373.00^{a} \pm 6.70$ \\
\hline Camel milk & $182.60^{\mathrm{bcd}} \pm 3.36$ & $91.40^{b c} \pm 1.50$ & $3.04^{b} \pm 0.12$ & $294.00^{\mathrm{bcd}} \pm 13.27$ \\
\hline $\mathrm{FCM}^{\star \star *}$ & $187.80^{\mathrm{bc}} \pm 4.80$ & $95.40^{b c} \pm 2.94$ & $2.88^{b} \pm 0.1$ & $298.00^{\mathrm{cd}} \pm 6.57$ \\
\hline Dandelion & $175.20^{\mathrm{cd}} \pm 6.44$ & $76.80^{\mathrm{de}} \pm 5.86$ & $3.00^{b} \pm 0.71$ & $280.40^{\mathrm{cd}} \pm 7.53$ \\
\hline Synbiotic & $180.60^{\mathrm{bcd}} \pm 3.59$ & $84.40^{\mathrm{cd}} \pm 4.74$ & $3.04^{b} \pm 0.12$ & $285.00^{\mathrm{cd}} \pm 9.75$ \\
\hline Whey & $169.60^{d} \pm 6.57$ & $71.00^{e} \pm 3.44$ & $3.14^{\mathrm{b}} \pm 0.1$ & $257.00^{d} \pm 16.40$ \\
\hline Casein & $196.60^{\mathrm{b}} \pm 2.66$ & $102.80^{\mathrm{b}} \pm 2.87$ & $2.74^{b c} \pm 0.15$ & $327.00^{b} \pm 21.19$ \\
\hline
\end{tabular}

Data are mean $\pm S E, n=5$, Different uppercase letters in the same column represent statistically significant data at $5 \%$; "Normal control group; " Injury control group; ${ }^{* *}$ Fermented camel milk. 
dandelion extract (prebiotic); probiotic product fortified with prebiotic product (synbiotic product), camel whey and camel casein protein reduced significantly the levels of malondialdehyde compared to liver injury control group which confirms that all treatment groups could effectively protect against oxidative stress induced by $\mathrm{CCl}_{4}$.

Glutathione acts as an antioxidant according to the liver defense mechanism to eliminate the toxicants from our body. The changes in serum glutathione (GSH) level of different groups has been tabulated in Table (4), rats treated with $\mathrm{CCl}_{4}$ (IC) significantly lowered the glutathione (GSH) level. While, other protective treatment groups elevated the level of glutathione in the serum indicated the roll of camel milk; fermented camel milk (probiotic product); dandelion extract; probiotic product fortified with prebiotic product (synbiotic product), camel whey and camel casein protein to activate the glutathione function as an antioxidant to scavenging free radical; pretreatment with camel milk can prevent the occurrence of oxidative damage; this result is in agreement with that of Houda et al (2017) demonstrated that camel milk attributed to its wealth in vitamins $A, B 2, C, E$ and its richness in zinc and higher level in magnesium which plays an important role in the biosynthesis of $\mathrm{GSH}$.

Table 4. Oxidative stress parameters of rat's different experimental groups

\begin{tabular}{|c|c|c|}
\hline Parameters & $\begin{array}{c}\text { MDA } \\
(\mathbf{n m o l} / \mathbf{m l})\end{array}$ & $\begin{array}{c}\text { GSH } \\
(\mathbf{m g} / \mathbf{d l})\end{array}$ \\
\hline $\mathbf{N C}^{*}$ & $5.7^{\mathrm{d}} \pm 0.27$ & $23.4^{\mathrm{a}} \pm 1.36$ \\
IC $^{\star \star}$ & $17.4^{\mathrm{a}} \pm 1.21$ & $7.0^{\mathrm{d}} \pm 0.71$ \\
Camel milk $^{*}$ & $10.0^{\mathrm{bc}} \pm 0.71$ & $15.5^{\mathrm{bc}} \pm 0.50$ \\
FCM $^{\star \star *}$ & $11.1^{\mathrm{b}} \pm 0.71$ & $16.1^{\mathrm{b}} \pm 0.91$ \\
Dandelion & $10.8^{\mathrm{bc}} \pm 1.15$ & $15.9^{\mathrm{b}} \pm 1.19$ \\
Synbiotic & $11.0^{\mathrm{bc}} \pm 1.30$ & $15.0^{\mathrm{bc}} \pm 0.71$ \\
Whey & $8.7^{\mathrm{c}} \pm 0.54$ & $17.6^{\mathrm{b}} \pm 1.63$ \\
Casein & $12.2^{\mathrm{b}} \pm 1.28$ & $12.6^{\mathrm{c}} \pm 0.93$ \\
\hline
\end{tabular}

Data are mean $\pm S E, n=5$, Different uppercase letters in the same column represent statistically significant data at $5 \%$; "Normal control group; "Injury control group; "**Fermented camel milk.

\section{Histopathological examination}

Hepatic injury by carbon tetrachloride $\left(\mathrm{CCl}_{4}\right)$ produce lipid peroxidation which caused oxidative stress; so we need to evaluate the potential protective effects of camel milk; fermented camel milk (probiotic product); dandelion extract( prebiotic product); probiotic product fortified with prebiotic product (Synbiotic product), camel casein and camel whey protein.

Liver injury was evaluated by histopathological alterations finding in Micrograph (1) to (8) and Table (5). There was no histopathological alteration and the normal histological structure of the central vein and surrounding hepatocytes were recorded in the normal control group (NC); (Micrograph 1).

Sever dilatation and congestion was observed in the central vein, associated with focal necrosis as well as focal inflammatory cells aggregation in the parenchyma. There was focal fibrosis with inflammatory cells aggregation in between the dilated central and portal veins. The portal area showed congestion in the portal vein, multiple newly formed bile ducts, few inflammatory cells infiltration and oedema were noticed in the injury control group (IC); (Micrograph 2).

The hepatic sections obtained from animals treated with $\mathrm{CCl}_{4}$ plus received camel milk showed very few inflammatory cells infiltration in the portal area (Micrograph 3). These results were confirmed by Thnaian, (2012) who reported that rats were treated with camel milk observed hepatic recovery and regeneration of hepatocytes; also, reduced the incidence of liver lesions induced by $\mathrm{CCl}_{4}$.

The liver sections obtained from animals treated with $\mathrm{CCl}_{4}$ plus received fermented camel milk observed hyperplasia in the lining epithelium of the bile ducts (Micrograph 4).

The hepatic sections obtained from animals treated with $\mathrm{CCl}_{4}$ plus received dandelion aqueous extract showed kupffer cells were proliferated in diffuse manner between the hepatocytes in association with dilatation in the central vein (Micrograph 5). These results were previously supported by Park et al (2010) who reported that dandelion leaf aqueous extract had a protective effect against $\mathrm{CCl}_{4}$-induced liver injury in rats.

The liver sections obtained from rats treated with $\mathrm{CCl}_{4}$ plus received synbiotic camel milk observed mild dilatation in the central vein and sinusoids with diffuse kupffer cells proliferation between the hepatocytes (Micrograph 6).

The hepatic sections from rats treated with $\mathrm{CCl}_{4}$ plus received camel whey protein was detected inflammatory cells infiltration in the portal area as well as between the hepatocytes (Micrograph 7). 


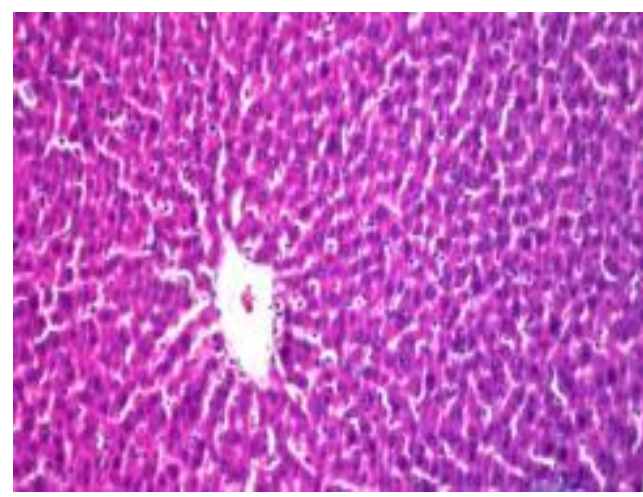

Micrograph 1. Liver of normal control rat $(H \& E, 40 X)$

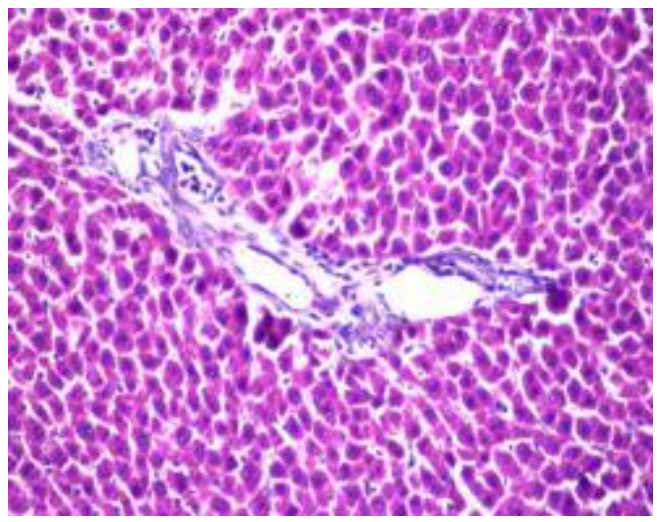

Micrograph 3. Liver of camel milk and $\mathrm{CCl}_{4}$-treated rat (H \& E, 40X).

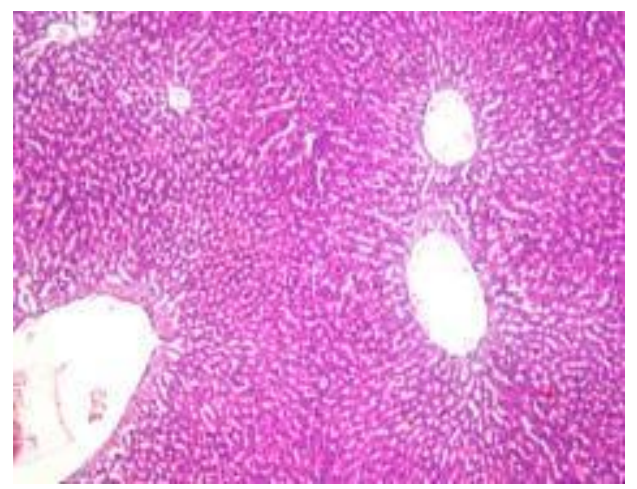

Micrograph 5. Liver of dandelion aqueous extract and $\mathrm{CCl} 4$-treated rat $(\mathrm{H} \& \mathrm{E}$, 40X)

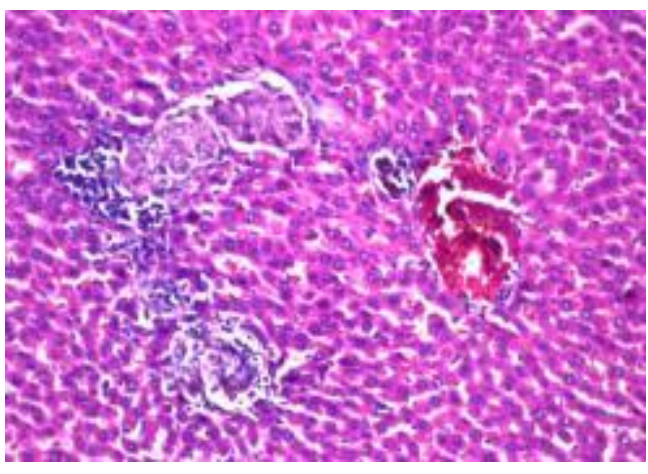

Micrograph 2. Liver of $\mathrm{CCl}_{4}$-treated rat $(\mathrm{H}$ \& $\mathrm{E}$, 40X).

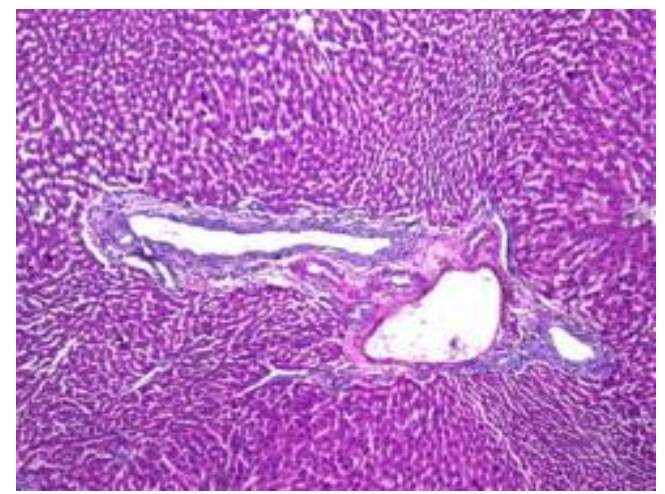

Micrograph 4. Liver of fermented camel milk and $\mathrm{CCl}_{4}$-treated rat $(\mathrm{H} \& \mathrm{E}, 40 \mathrm{X})$.

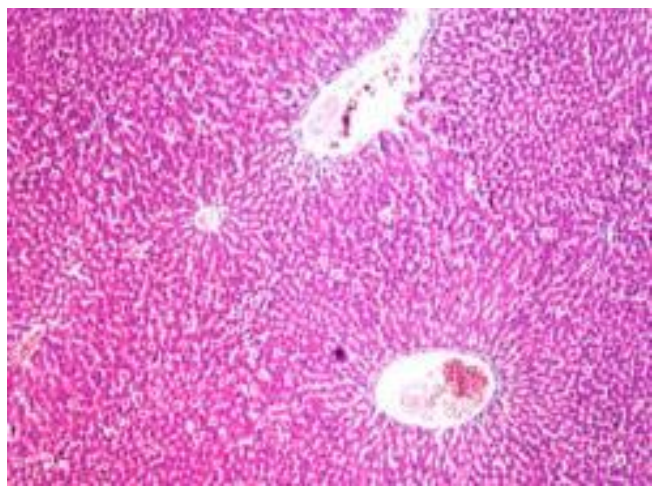

Micrograph 6. Liver of synbiotic camel milk and $\mathrm{CCl} 4$-treated rat ( $\mathrm{H} \& \mathrm{E}, 64 \mathrm{X})$. 


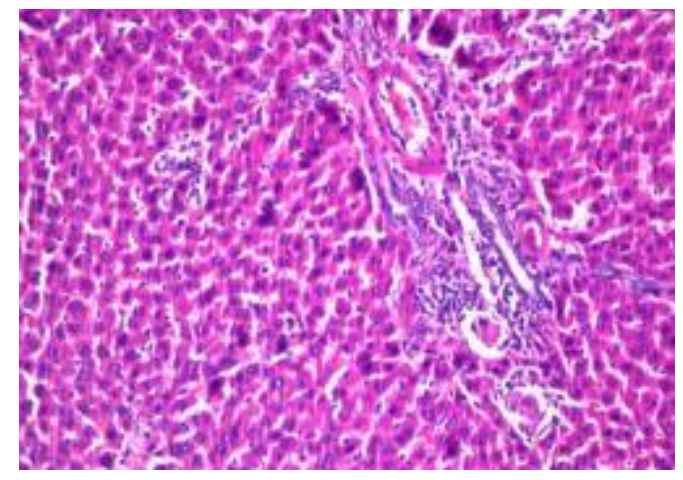

Micrograph 7. Liver of camel whey protein and $\mathrm{CCl} 4$-treated rat (H \& E, 40X).

The liver sections from rats treated with $\mathrm{CCl}_{4}$ plus camel casein showed dilatation in the central vein. The portal area showed inflammatory cells infiltration and hyperplasia in the lining epithelium of the bile ducts. Fatty change was detected in some few individual hepatocytes (Micrograph 8).

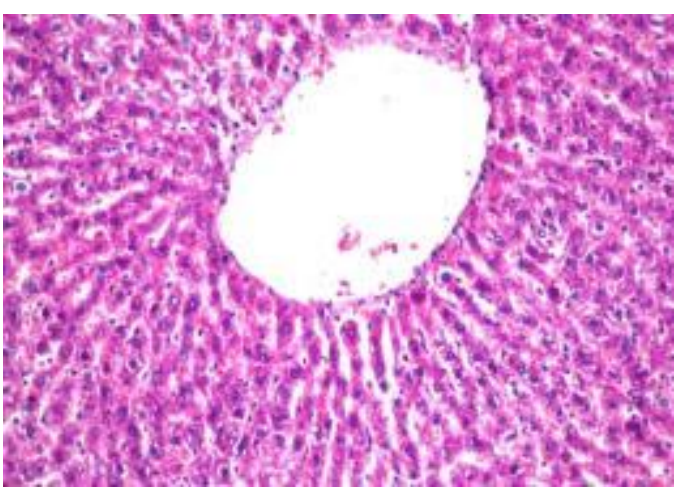

Micrograph 8. Liver of camel casein and CCl4-treated rat $(\mathrm{H} \& \mathrm{E}, 40 \mathrm{X})$.

The histopathological changes in treated groups with camel milk; fermented camel milk (probiotic product); dandelion extract (prebiotic product); probiotic product fortified with prebiotic product (synbiotic product), camel casein and camel whey protein as compared to that induced with $\mathrm{CCl}_{4}$ alone indicated marked protective effects of these substances (Table 5).

Table 5. Histopathological severity changes in rat liver of different experimental groups

\begin{tabular}{|c|c|c|c|c|c|c|c|c|}
\hline Alteration & NC & IC & $\begin{array}{l}\text { Camel } \\
\text { milk }\end{array}$ & FCM & Dandelion & Synbiotic & $\begin{array}{l}\text { Whey } \\
\text { protein }\end{array}$ & Casein \\
\hline Congestion & - & ++ & - & - & + & + & - & + \\
\hline Focal hepatic necrosis & - & + & - & - & - & - & - & - \\
\hline $\begin{array}{l}\text { Focal inflammatory cell in the } \\
\text { parenchyma }\end{array}$ & - & ++ & - & - & - & - & - & - \\
\hline $\begin{array}{c}\text { Focal fibrosis in hepatic } \\
\text { parenchyma }\end{array}$ & - & + & - & - & - & - & - & - \\
\hline Portal inflammatory rectum & - & ++ & + & - & - & - & + & - \\
\hline $\begin{array}{l}\text { Hyperplasia and proliferation } \\
\text { of bile ducts }\end{array}$ & - & ++ & - & ++ & - & - & - & + \\
\hline Kupffer cell proliferation & - & - & - & - & + & + & - & - \\
\hline Fatty change in hepatocytes & - & - & - & - & - & - & - & + \\
\hline
\end{tabular}

- : Nil; +: Mild; ++: Moderate; +++: Severe effect. 

controlling against liver injury

\section{CONCLUSION}

As appeared from the aforementioned data, treatment by camel milk ; fermented camel milk (probiotic product); dandelion extract( prebiotic product) ; probiotic product fortified with prebiotic product (synbiotic product), camel whey and camel casein protein improved liver function and decreased the oxidative stress induced by $\mathrm{CCl}_{4}$ in rats; in addition, histopathological examinations in the hepatic confirmed protective ability of these treatments.

\section{REFERENCES}

Abdel-Salam A.M., El-Ziney M.G., Zaghloul A.H., Babiker A.Y. and Moussa H.M. 2009. The effectiveness of whey proteins mixed with hotwater extract of Artemisia and Capparis spp. against lead acetate-contamination in rats. $\mathbf{J}$. of Food Agric. and Environment, 7(3\&4), 139-141.

ADA, 2000. American Dietetic association, Manual of Clinical dietic. (ADA) $6^{\text {th }}$ Ed., Chicago. USA.

Al-Fartosi K.G., Majid A.M. and Hussein M.H. 2012. The Role of Camel's Milk against Some Oxidant-Antioxidant Markers of Male Rats Treated With $\mathrm{CCl}_{4}$. Int. J. Res. Pharmaceutical and Biomedical Sci., 3, 385-389.

Badr G., Badr B.M., Mahmoud M.H., Mohany M., Rabah D.M. and Garraud O. 2012. Treatment of diabetic mice with undenatured whey protein accelerates the wound healing process by enhancing the expression of MIP-1 $1 \alpha$, MIP-2, KC, CX3CL1 and TGF- $\beta$ in wounded tissue. BMC Immunol. 13(1), 1.

Banchroft J., Stevens A. and Turner D. 1996. Theory and Practice of Histological Techniques. $4^{\text {th }}$ Ed. Churchil Livingstone, New York, USA.

Beutler E., Duron O. and Kelly B.M. 1963. Improved method for the determination of blood glutathione. J. Lab. Clin. Med., 61, 882-888.

Bloor S. 2001. Overview of methods for analysis and identification of flavonoids, Methods in Enzymology, 335, 3-14.

Brand-Williams W., Cuvelier M.E. and Berset C. 1995. Use of a free radical method to evaluate antioxidant activity. Lebensm.-Wiss. u.Technol. LWT, 28, 25-30.

Doumas B.T., Waston W.A. and Biggs H.G. 1971. Albumin standards and the measurement of serum albumin with bromocresol green. Clin Chim Acta., 31, 87-96.
El-Agamy E.I., Nawar M., Shamsia S.M., Awad S. and Haenlein G.F.W. 2009. Are camel milk proteins convenient to the nutrition of cow milk allergic children? Small Rumin. Res. 82, 1-6.

El-ouardy K., Mohamed I., Lorenzo M.P.C., Paula F.B., Nadia S.S. and Jamal A. 2011. Antimicrobial Activities of the Bacteriocin-like Substances Produced by Lactic Acid Bacteria Isolated from Moroccan Dromedary Milk. African J. of Biotechnology, 10, 10447-10455.

Heller K.J. 2001. Probiotic bacteria in fermented foods: product characteristics and starterorganisms. Am. J. Clin. Nutr., 73, 374-379.

Houda H., Manel G., Khaled B., Zied G., Abdelfattah E. and Ahmed G. 2017. Cardiopreventive effects of camel milk against carbon tetrachloride induced oxidative stress, biochemical and histological alterations in mice. Arch Physiol Biochem., 124(3), 253-260.

Huth P.J., Layman D.K. and Brown P.H. 2004. The emerging role of dairy proteins and bioactive peptides in nutrition and health. J. of Nutrition. 134(4), 961S.

Kim J., Noh K., Cho M., Jang J. and Song Y. 2007. Anti-oxidative, anti-inflammatory and anti-atherogenic effects of dandelion (Taraxacum officinale) extracts in C57BL/6 mice fed atherogenic diet. FASEB J., 21, 862-867.

Magjeed N.A.A. 2004. The curative action of Arabian milk camel on some cancer bio markers in rat liver intoxicated with flatoxin $B$, J. of the Saudi Chemical Society, 8(2), 233-240.

Mahan K.L. and Escott-Stump S. 1996. Krause's Food Nutrition and Diet therapy. (9 $9^{\text {th }}$ Ed.), Philadelphia, USA, pp. 771-773.

Małgorzata K., Ewa I., Marek M., Małgorzata E., Katarzyna M. and Jodynis-Liebert J. 2009. Protective effect of red beetroot against carbon tetrachloride- and n-nitrosodiethylamineinduced oxidative stress in rats. J. Agric. Food Chem. 57, 2570-2575.

Meisel H. 2005. Biochemical properties of peptides encrypted in bovine milk proteins. Current Medicinal Chemistry. 12, 1905-1919

Mervat E. Gaffar 2008. Studies on Assessment of nutraceutical proteins of som dairy foods. Ph.D. Thesis. Food. Sci. Dep. Fac. Agri. Ain Shams Univ., Cairo, Egypt. pp. 39-40.

Muller M.S. and Mechler E. 2005. Medicinal plants in Tropical countries. Traditional Use Experience- Facts. Thieme, Stuttgart, Germany. 
Nishino T., Shibahara-Sone H., KikuchiHayakawa H. and Ishikawa F. 2000. Transit of radical scavenging activity of milk products prepared by maillardreaction and Lactobacillus casei Strain Shirotafermentation through the hamster intestine. J. Dairy Sci., 83(5), 915922.

Ohkawa H., Ohishi N. and Yagi K. 1979. Assay for lipid peroxides in animal tissues by thiobarbituric acid reaction. Anal. Biochem. 95, 351358.

Park C.M., Youn H.J., Chang H.K. and Song Y.S. 2010 a. TOP1 and 2, polysaccharides from Taraxacum officinale, attenuate $\mathrm{CCl} 4$ - induced hepatic damage through the modulation of NF-jB and its regulator mediators. Food Chem. Toxicol 48, 1255-1261.

Park C.M., Cha Y.S., Youn H.J., Cho C.W. and Song Y.S. 2010 b. Amelioration of oxidative stress by dandelion extract through CYP2E1 suppression against acute liver injury induced by carbon tetrachloride in sprague-dawley rats. Phytother Res. 24, 1347-1353.

Parvez S., Malik K.A., Ah Kang S. and Kim H.Y. 2006. Probiotics and their fermented food products are beneficialfor health. J. Appl. Microbiol.100, 1171-1185.

Reeves P.G., Nielsen F.H. and Fahey G.C.Jr. 1993. AIN-93 purified diets for laboratory rodents: final report of the American Institute of Nutrition ad hoc writing committee on the reformulation of the AIN-76A rodent diet. J. Nutrition, 123(11), 1939-1951.

Reid G., Gaudier E., Guarner F., Huffnagle G.B., Macklaim J.M., Munoz A.M., Martini M., Ringel-Kulka T., Sartor B.R., Unal R.R., Verbeke K. and Walter J. 2010. Responders and nonresponders to probiotic interventions. How can we improve the odds. Gut Microbes J., 1(3), 200-204.
Reitman S. and Frankel S. 1957. A colourimetric method of the determination of plasma glutamic oxaloacetic and glutamic pyruvic transaminases. Am. J. Clins. Pathol., 28, 56-63.

Rouanet J.M., Kelly D., Daniele D.R., Cyril A., Gina B., Jean-Paul C., Michael E.J.L. and Alan C. 2010. Berry juices, teas, antioxidants and the prevention of atherosclerosis in hamsters. Food Chem. 118, 266-271.

SAS, 2003. SAS/ Stat Users Guide: Statistics, System for Windows, version 4.10 (release 8.01 TS level 01M0), SAS Inst., Inc. Cary, North Carolina, USA.

Schütz K., Carle R. and Schieber A., 2006. Taraxacum - a review on its phytochemical and pharmacological profile. J. of Ethnopharmacology, 107(3), 313-323.

Tamime A.Y. and Robinson R.K. 1999. Yogurt Science and Technology. Cambridge, (eds.) UK: Wood head Publishers, pp. 30-31.

Thnaian A. 2012. Protective effect of camel milk against carbon tetrachloride hepatotoxicity in rats. Global Veterinaria, 9(5), 564-570.

Tietz N.W., Rinker D. and Shaw L.M. 1983. International Federation of Clinical Chemistry. IFCC methods for the measurement of catalytic concentration of enzymes. Part 5. IFCC method for alkaline phosphatase. J. Clin. Chem. Clin. Biochem, 21, 731-748.

Yagil R., Zagorski O., Van Creveld C. and Saran A. 1994. Science and camel milk production. Chameaux et dromadaire, animaux laitiers. Francais, Paris, pp. 75-89.

Yansong X., Shuming Z., Min D. and Mei-Jun Z. 2017. Dandelion extract suppresses reactive oxidative species and inflammasome in intestinal epithelial cells. J. of Functional Foods. 29, 10-18. 


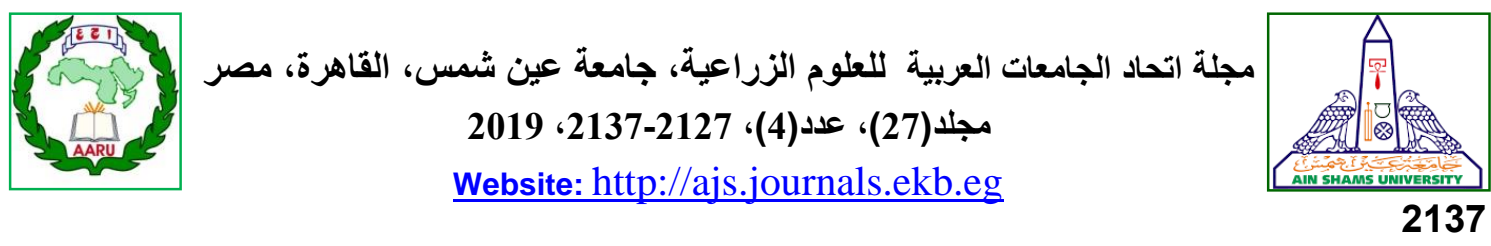

حليب الإبل والمستخلص المائي لأورلق الهندباء كعوامل مساعدة للتحم فى الضرر الكبدي

[169]

$$
\begin{aligned}
& \text { مروه محسن يوسف1" - محمد عبدالله الحوفى2 - إيهاب صلاح عشوش2 - كمال أسعد سوريال } 1 \text { - } \\
& \text { صفاء عبد العزيز احمد } 3
\end{aligned}
$$

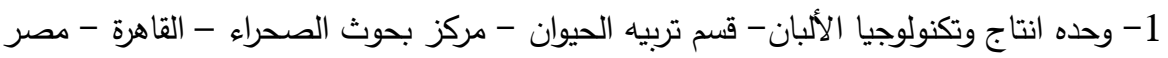

$$
\begin{aligned}
& \text { 2- قسم علوم الأغذية - كلية الزراعة - جامعة عين شمس - صدئب } 68 \text { - } 68 \text { - حدائق شبرا } \\
& \text { 3- شعبة التقيم الغذائى وعلوم الاغذيه - الهيئه القوميه للرقابه والبحوث الدوائيه - الجيزه - مصر }
\end{aligned}
$$

Received 8 September, 2019 Accepted 25 September, 2019

أشارت النتائج إلى أن جميع المواد السابقة أظهرت

نشاط ايجابيا وقد كثفت المجموعة الضابطة المصابة

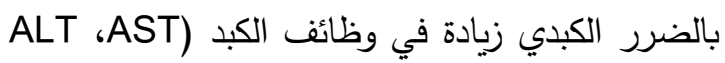

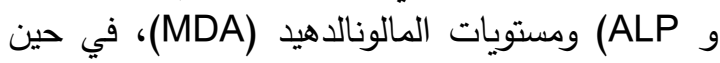
انخفضت معدل زيادة وزن الجسم ومستويات الزيات الزلال

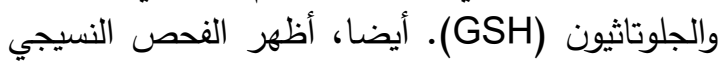

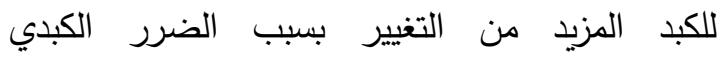

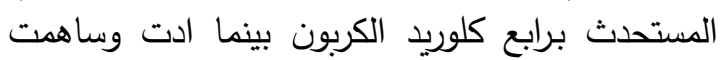

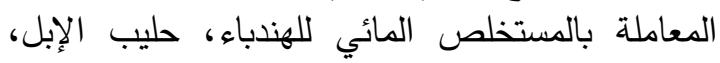

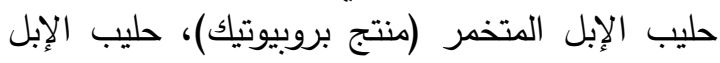

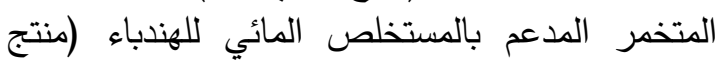
سينابيوتيك)، كازين الإبل وبروتين شرش حليب الإبل اليل

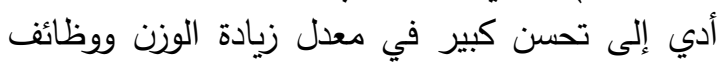

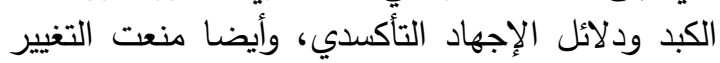

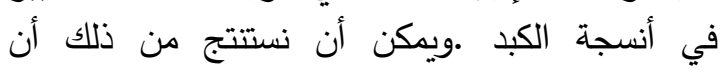

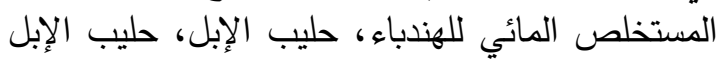

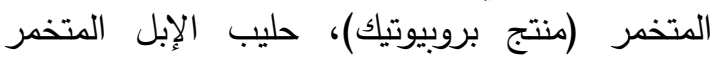

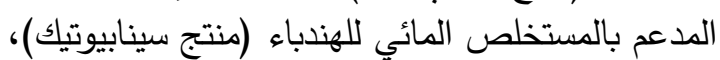

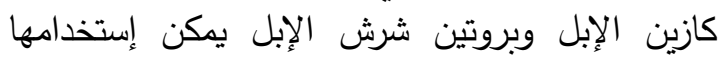
كمكونات في الأغذية الوظيفية لوقاية الكبد.

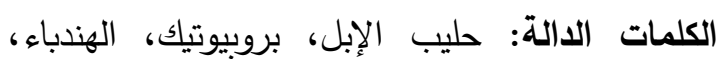
الضرر الكبدي، الفئران

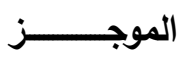

يهتم الناس في جميع أنحاء العالم إهتمام كبير بطرق الوقاية من امراض الكبد، والنظام النيام الغذائي

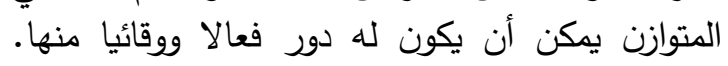
لذلك، تهدف هذه الدراسة إلى التحقق من الدون دور الوقائي

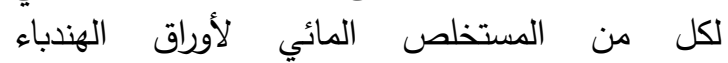

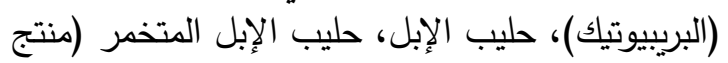

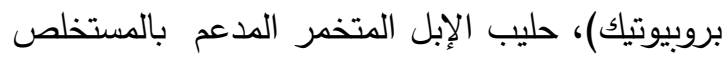
المائي لأوراق الهندباء (منتج سينابيوتيك) وكازين الإبل الإبل

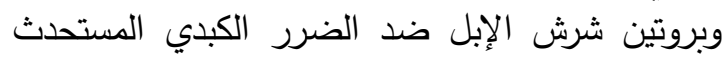

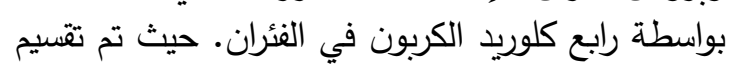
الفئران إلى ثماني مجموعات (ثمانية فئران لكل منهما).

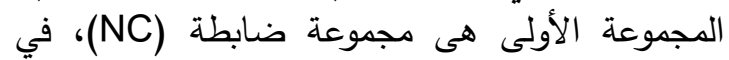
حين تم حقن المجموعات السبع الأخرى فى بدائه

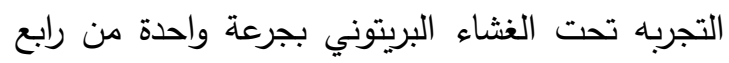

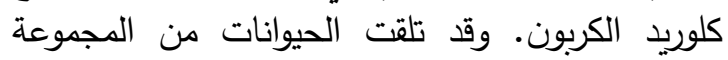

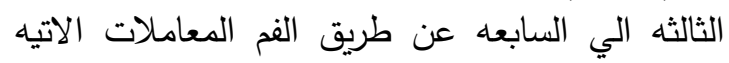

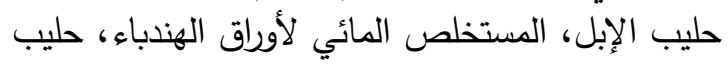

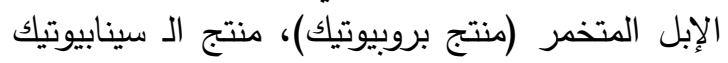

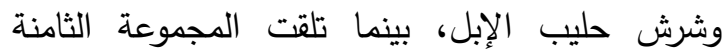

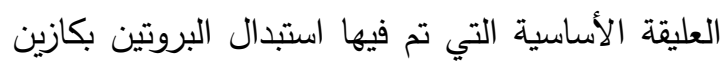
الإبل بنسبة 20٪ واستمرت التجربه لمدة 45 يوم.

تحكيم: ا.د أحمد محمد عبدالسلام د. - أسامة إبراهيم البطاوي 



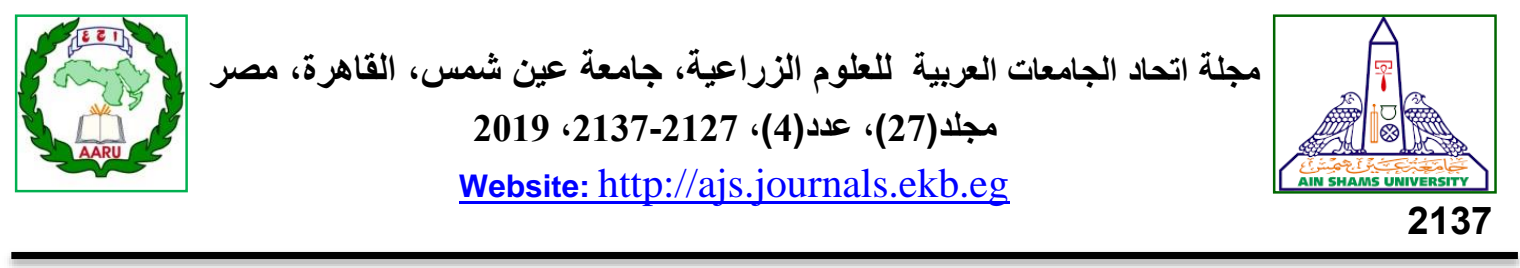

تحكيم: ا.د أحمد محمد عبدالسلام د. أسامة إبراهيم البطاوي 